\title{
Degtyar M.
}

\section{INTENSIFICATION OF WASTEWATER PURIFICATION OF MUNICIPAL SOLID WASTE LANDFILLS}

Об'єктом дослідження є дренажні води полігонів твердих побутових відходів (ТПв) $і$ ефективність застосування комбінацї різних технологічних прийомів, зокрема, поєднання реагентного та біологічного методів задля доведення якості фільтрату до нормативних вимог. Зокрема, досягається зниження негативного впливу дренажних вод полігонів ТПВ, які містять токсичні органічні забруднювачі, на навколишнє природне середовище та здоров'я людини.

В ході досліджень був проведений порівняльний аналіз ефективності використання звичайного та активованого розчину коагулянту сульфату алюмінію. Отримано певну залежність параметрів активації та ефективності очищення фільтрату полігонів ТПВ. Для досягнення поставленої у роботі мети був вивчений хімічний склад фільтрату полігонів на різних етапах експлуатації та проведена оптимізація параметрів реагентного очищення стічних вод полігонів ТПВ. А також вивчена кінетика та виявлені закономірності процесу коагулячї при активацї розчину коагулянту.

При проведенні досліджень була апробована запропонована у роботі технологія, проведені досліднопромислові випробування та виконаний аналіз техніко-економічної ефективності реалізації технології. При виконанні експериментальних досліджень використовувався комплекс методик визначення рівнів рН, ХПК (хімічне споживання кисню), БПК (біологічне споживання кисню) та ін. Доведено високу ефективність використання реагентного методу в комбінації з біологічним очищенням для фільтраційних вод, характерних для стадї метаногенезу. Запропонована технологія має ряд особливостей, зокрема, протягом активацї розчину реагенту відбувається накладення магнітного поля, внаслідок чого відбувається зміна структури розчину і утворення додаткових центрів коагуляиї.

В роботі представлено результати дослідження технологічної та економічної ефективності запропонованої технології, зокрема, доведено зниження експлуатаційних витрат при запровадженні розглянутої технологічної схеми та запропонованого апаратурного оформлення. У порівнянні з іншими відомими технологіями, що мають стадію реагентного очищення, це дозволить інтенсифікувати процес коагуляцї та знизити розрахункову дозу коагулянту на 25-30\%, без погіршення якості очищення.

ключові слова: полігон твердих побутових відходів, активований розчин коагулянту, іонні асоціати, анодно-розчинне залізо, доза коагулянту.

\section{Introduction}

Purification of the filtrate is a complex task, both from a technological and from an economic point of view. The one-step scheme for purifying the filtrate does not allow achieving a high efficiency of purification of the filtrate [1-3]. The main factor ensuring the required quality of the filtrate at the exit is the multistage process using reagent purification to facilitate and complete the flow of the subsequent stages [4, 5]. Physical, chemical, biological methods, as well as their combination, are used to purify highly concentrated wastewaters of municipal solid waste (MSW) landfills [5-7]. In particular, in [6, 7], it is proposed to use the stage of reagent purification and electrolytic purification, as well as optimization of parameters of reagent wastewater purification using $\mathrm{FeSO}_{4}$. And in [8], the use of denitrification at the stage of stable methanogenesis using the columns filled with digestate is proposed. Thus, it is relevant to assess the use of a combination of these methods using an activated solution of aluminum sulfate coagulant, by magnetic purification and electrocoagulation. Therefore, the object of research is the wastewaters of MSW landfills and the effectiveness of using a combination of various technological methods, in particular, a combination of reagent and biological methods for bringing the quality of filtrate to regulatory requirements. The aim of research is a theoretical feasibility study on the application of the proposed purification technology, in particular, an activated coagulant solution.

\section{Methods of research}

The quality of the filtrate is directly related to the operation stage of the landfill («young filtrate» is characteristic of the stage of acetogenesis, «old filtrate» - the stage of methanogenesis). Thus, the stage of biochemical decomposition of waste determines the qualitative and quantitative characteristics of wastewater.

As a rule, the purification of wastewater requires a multistage combination of various physicochemical and biological methods, significant capital and operating costs.

Laboratory studies were performed using optical and physico-chemical methods. Studies on the effectiveness of the use of the selected technology for purification of wastewaters of MSW landfills were carried out both in laboratory conditions and at the pilot plant.

Regularities of wastewater purification using an activated reagent solution were studied on model water and 
wastewater generated at the MSW landfill, characteristic of the stage of stable methanogenesis.

The qualitative characteristics of wastewater are given in Table 1. The experiment was performed in parallel for the conditions of conventional coagulation and for waste water purified with an activated solution of aluminum sulfate coagulant.

To activate the reagent solutions, a magnetic activator is used, which provides for simultaneous and sequential activation of the solution by the magnetic field and saturation with an anodically dissolved iron [9, 10].

Table 1

Qualitative characteristic of wastewaters of the MSW landfill (Zaporizhzhia, Ukraine)

\begin{tabular}{|c|c|c|c|}
\hline \multirow{2}{*}{ Indicator } & \multicolumn{3}{|c|}{ Research period } \\
\hline & Winter & Spring & Autumn \\
\hline Dry residue, $\mathrm{mg} / \mathrm{dm}^{3}$ & 18052.7 & 22880.5 & 21514.3 \\
\hline $\mathrm{BOD}_{5}, \mathrm{mgO} / \mathrm{dm}^{3}$ & 167.8 & 166 & 186.5 \\
\hline $\mathrm{COD}, \mathrm{mg} / \mathrm{dm}^{3}$ & 1215.6 & 995 & 1000 \\
\hline Chromaticity, deg. & 166 & 158 & 170 \\
\hline Suspended substances, $\mathrm{mg} / \mathrm{dm}^{3}$ & 273 & 208.7 & 260.4 \\
\hline $\mathrm{pH}$ & 7.3 & 7.5 & 7.6 \\
\hline Nitrogen, mg/dm ${ }^{3}$ & 260 & 83.2 & 61 \\
\hline Nitrates, $\mathrm{mg} / \mathrm{dm}^{3}$ & 118.2 & 102.8 & 106.4 \\
\hline Sulfates, $\mathrm{mg} / \mathrm{dm}^{3}$ & 2109.2 & 2216.6 & 1490.3 \\
\hline
\end{tabular}

Note: $\mathrm{BOD}_{5}$ - biological oxygen demand (for 5 days); COD - chemical axygen demand

The activation mechanism is explained by the imposition of a magnetic field on the solutions, resulting in a change in their structure and the formation of ionic associates, which are the nuclei of a new phase and act as additional coagulation centers.

The stabilization of ionic associates occurs with anodic dissolved iron, the content of which does not exceed $1000-1500 \mathrm{mg} / \mathrm{dm}^{3}$ of a $10 \%$ solution of aluminum sulfate coagulant [10, 11].
Pilot industrial tests were performed at the MSW landfill in Zaporizhzhia (Ukraine). As a result of research, it is found that the use of an activated solution of aluminum sulphate can improve the quality of the filtrate, reduce the dose of reagents, reduce the size of the reagent economy.

To assess the effectiveness of the implementation of wastewater purification technology using an activated solution of aluminum sulfate at the purification stage, the following is determined:

- cleaning efficiency;

- economic effect of the introduction of the developed technology.

According to the proposed technology, wastewater enters the collection to ensure uniform and uninterrupted supply. The reagent activator is installed on the bypass line and is used according to the research regulations. In the mixer, the coagulant solution (activated or normal - according to the regulations) is mixed with wastewater, then the filtrate is sent to the primary clarifier, a bath with immersion biodisks and a secondary clarifier section. After the secondary settling tank, disinfection with bactericidal irradiation is organized. As an aftertreatment filter with quartz sand is used.

\section{Research results and discussion}

After completing the experiments, the following samples were taken to analyze the effectiveness of the proposed technology:

- source filtrate - indicators: suspended matter content, chromaticity, COD, BOD full;

- purified filtrate - indicators: suspended matter content, chromaticity, COD, BOD full.

The main criterion for the effectiveness of the application of the activation of the coagulant solution is the residual content of suspended substances, the indicators of the efficiency of biological purification - $\mathrm{BOD}_{\text {full }}$ and COD. Comparative effectiveness of conventional and activated solution of coagulant aluminum sulphate is given in Table 2 . The economic efficiency of the introduction of an activated solution of aluminum sulfate is also determined, according to the results of pilot tests of a pilot plant (Table 3 ).

Table 2

The effectiveness of conventional and activated coagulant solution of aluminum sulfate

\begin{tabular}{|c|c|c|c|c|c|c|c|c|c|c|c|c|c|c|c|c|c|}
\hline \multirow[b]{2}{*}{$\begin{array}{c}\text { Series of } \\
\text { experiments }\end{array}$} & \multirow[b]{2}{*}{ Date } & \multicolumn{4}{|c|}{ Indicators of the initial wastewater } & \multicolumn{2}{|c|}{$\begin{array}{l}\text { Activation } \\
\text { options }\end{array}$} & \multirow{2}{*}{ 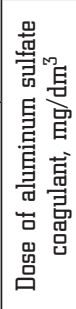 } & \multicolumn{4}{|c|}{$\begin{array}{l}\text { Indicators of purified } \\
\text { wastewater }\end{array}$} & \multirow{2}{*}{ 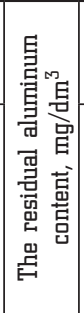 } & \multicolumn{4}{|c|}{$\begin{array}{l}\text { Improving the per- } \\
\text { formance of purified } \\
\text { wastewater, } \%\end{array}$} \\
\hline & & 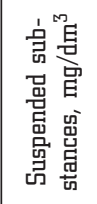 & 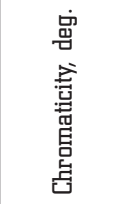 & $\begin{array}{l}\text { 县 } \\
\text { 员 } \\
\text { 品 } \\
\text { 号 }\end{array}$ & 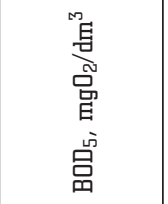 & 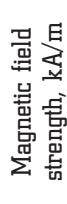 & 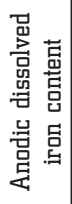 & & 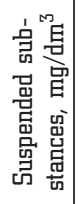 & 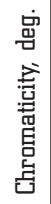 & 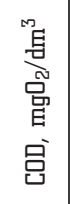 & 㖞 & & 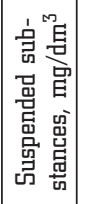 & $\begin{array}{l}\text { 䙲 } \\
\text { 䓌 } \\
\text { 票 } \\
\text { 总 }\end{array}$ & $\begin{array}{l}\text { 县 } \\
\text { 品 } \\
\text { 品 } \\
\text { 号 }\end{array}$ & 号 \\
\hline $\begin{array}{l}\text { I (conventio- } \\
\text { nal coagulant } \\
\text { solution) }\end{array}$ & $\begin{array}{l}2.09 .17- \\
15.09 .17\end{array}$ & $\begin{array}{c}255.4- \\
267.5\end{array}$ & $150-165$ & $\begin{array}{l}994.7- \\
1006.5\end{array}$ & $172.3-184.5$ & 325 & 12.5 & 210 & 13.5 & 36 & 28.9 & 9.3 & 0.35 & - & - & - & - \\
\hline $\begin{array}{l}\text { II (activated } \\
\text { coagulant } \\
\text { solution) }\end{array}$ & $\begin{array}{l}16.09 .17- \\
29.09 .17\end{array}$ & $\begin{array}{c}265.4- \\
271.5\end{array}$ & $152-164$ & $\begin{array}{c}1010.2- \\
1025.6\end{array}$ & $164.8-181.5$ & 325 & 12.5 & 210 & 7.7 & 19 & 19.8 & 6.3 & 0.15 & 43.0 & 47.2 & 31.5 & 32.3 \\
\hline $\begin{array}{l}\text { III (ordinary } \\
\text { coagulant } \\
\text { solution) }\end{array}$ & $\begin{array}{c}30.09 .17- \\
13.10 .17\end{array}$ & $\begin{array}{c}242.6- \\
269.3\end{array}$ & $157-172$ & $\begin{array}{c}1010.4- \\
1021.5\end{array}$ & $166.2-174.5$ & 325 & 12.5 & 210 & 13.4 & 34 & 26.4 & 9.1 & 0.25 & - & - & - & - \\
\hline $\begin{array}{l}\text { IV (activated } \\
\text { coagulant } \\
\text { solution) }\end{array}$ & $\begin{array}{c}14.10 .17- \\
27.10 .17\end{array}$ & $\begin{array}{c}238.2- \\
254.1\end{array}$ & $160-175$ & $\begin{array}{l}1029.3- \\
1051.6\end{array}$ & $147.8-161.5$ & 325 & 12.5 & 210 & 7.8 & 20 & 18.2 & 6 & 0.17 & 41.8 & 41.2 & 31.1 & 34.1 \\
\hline
\end{tabular}


Initial data for calculating the economic effect

\begin{tabular}{|c|c|c|c|c|c|}
\hline No. & Type of indicator & Legend & Units & Base version & Implement version \\
\hline 1 & Performance of purification facilities & $\square$ & $\mathrm{m}^{3} /$ day & 300 & 300 \\
\hline 2 & Average dose of coagulant $\mathrm{Al}_{2}\left(\mathrm{SO}_{4}\right)_{3}$ & $D_{c}$ & $g / m^{3}$ & 250 & 200 \\
\hline 3 & Annual consumption of coagulant $\mathrm{Al}_{2}\left(\mathrm{SO}_{4}\right)_{3}$ & $P_{c}$ & $\mathrm{~T}$ & 27.4 & 21.9 \\
\hline 4 & Cost of coagulant $\mathrm{Al}_{2}\left(\mathrm{SO}_{4}\right)_{3}$ & $\Sigma_{c}$ & USD/t & 360 & 360 \\
\hline 5 & Electricity cost & $\Sigma_{e}$ & USD/kW·h & 0.06 & 0.06 \\
\hline 6 & Cost of reagent activator & $\Gamma$ & USD & - & 200 \\
\hline 7 & Reagent activator power & $N$ & $\mathrm{~kW} \cdot \mathrm{h}$ & - & 0.5 \\
\hline
\end{tabular}

The cleaning scheme according to the basic variant includes: a reagent farm, a mixer, a primary and secondary settling tank, submersible biodisk filters, a bactericidal lamp and a frame-fill-in filter. The cost of the manufacture and installation of the reagent activator is equal to the cost of construction and reconstruction of the reagent economy in the base case.

According to the Table 3 and calculations (basic option), to clean $300 \mathrm{~m}^{3} /$ day of wastewater, $0.08 \mathrm{~m}^{3}$ of $10 \%$ normal and $0.06 \mathrm{~m}^{3}$ of activated aluminum sulfate coagulant solution is necessary (taking into account a $25 \%$ reduction in dose). Considering the required volume, the activator capacity is $0.01 \mathrm{~m}^{3} / \mathrm{h}$ with reagent activator duration of 6 hours per day.

It is expected that the annual economic effect from the introduction of an activated solution of aluminum sulfate coagulant will be about 2 thousand USD (compared to the base case).

The use of membrane technologies (disk-tube membranes) at the main stage can be justified by the possibility of their repeated use in the «filtration - regeneration filtration» cycles. However, operating costs (costs of maintenance and electricity) amount to about 35 thousand USD, including the annual replacement of modules, which is absolutely inexpedient for economic reasons.

\section{Conclusions}

It is shown that the intensification of wastewater purification processes of landfills using activated aluminum sulphate solution can be explained by the violation of the dynamic equilibrium of the water-dispersed system. This contributes to the formation of ionic associates, the nuclei of a new phase, which play the role of additional coagulation centers. An analysis of the conducted studies allows to conclude that the use of an activated coagulant solution can reduce the calculated dose by $25-30 \%$, without reducing the effectiveness of wastewater purification. In the process of cleaning, hardening of the flakes of the precipitate formed and an increase in the degree of its precipitation are also observed. It should also be noted that the proposed technology is more effective at the stage of methanogenesis, i. e., for the «old» filtrate, which is characterized by a more stable composition. When using this technology for a «young» filtrate (acid phase acetogenesis), it is necessary to adjust the activation parameters of the solution, increasing the magnetic field strength and the dose of anodic dissolved iron.

The results of this research will be useful in the development of technical documentation for the operation of solid waste landfills, as well as interesting to researchers in studying the difficulties in purifying specific concentrated wastewater.

\section{Refernces}

1. Ochistka drenazhnyh vod svalok tverdyh bytovyh othodov baromembrannymi metodami / Goncharuk V. V., Balakina M. N., Kucheruk D. D., Skubchenko V. F. // Himiia i tekhnologiia vody. 2006. Vol. 28, Issue 5. P. 462-471.

2. Stepaniuk A. P. Problema zneshkodzhennia filtratu ta shliakhy yii vyrishennia // Sanitarna ochystka mist ta komunalnyi avtotransport. 2002. Issue 4. P. 40-43.

3. Bolyard S. C., Reinhart D. R. Application of landfill treatment approaches for stabilization of municipal solid waste // Waste Management. 2016. Vol. 55. P. 22-30. doi: http://doi.org/ 10.1016/j.wasman.2016.01.024

4. Reinhart D. R. Active municipal solid waste landfill operation: A biochemical reactor // Waste Management. 1993. Vol. 13, Issue 5-7. P. 533. doi: http://doi.org/10.1016/0956-053x(93)90124-f

5. Resursosberegaiushchie tekhnologii ochistki stochnyh vod: monograph / Dushkin S. S., Kovalenko A. N., Degtiar M. V., Shevchenko T. A. Kharkiv: HNAGH, 2011. 168 p.

6. Kompleksnyi podhod $\mathrm{k}$ resheniiu problemy ochistki stochnyh vod poligonov tverdyh bytovyh othodov / Varnavskaia I. V., Stalinskii D. V., Epshtein S. I., Muzykina Z. S. // Vodoochistka. 2012. Issue 4. P. 7-14.

7. Stalinskii D. V., Iatskov N. V., Varnavskaia I. V. Issledovaniia po optimizatsii parametrov reagentnoi ochistki stochnyh vod poligonov tverdyh bytovyh othodov ot organicheskih zagriaznenii // Visnik NUVGP. Tekhnichni nauki. 2012. Issue 2 (58). P. $25-34$.

8. Denitrification of Mature Landfill Leachate with High Nitrite in Simulated Landfill Columns Packed with Solid Digestate from Organic Fraction of Municipal Solid Waste / Peng W. Pivato A., Cerminara G., Garbo F., Raga R. // Waste and Biomass Valorization. 2018. P. 1-11. doi: http://doi.org/10.1007/ s12649-018-0422-7

9. Sposib ochyshchennia stichnykh vod polihoniv tverdykh pobutovykh vidkhodiv: Pat. No. 45190 UA. MPK51 (2009) CO2F 1/48 / Solodovnyk M. V., Dushkin S. S., Tkachov V. O., Dushkin S. S., Korinko I. V.; u 200905845; declareted: 09.06.2009; published: 26.10.2009. Bul. No. 20.

10. Dehtiar M. V. Intensyfikatsiia protsesiv ochyshchennia vysokokontsentrovanykh stichnykh vod // Visnyk Natsionalnoho universytetu vodnoho hospodarstva ta pryrodokorystuvannia. 2015. Issue 1 (69). P. 111-116.

11. Solodovnik M. V. Granichnye usloviia primeneniia metodov ochistki drenazhnih vod poligonov tverdyh bytovyh othodov // Gidromelioratsiia ta gidrotekhnichne budivnitstvo. 2009. Issue 34. P. 309-314.

Degtyar Maria, PhD, Associate Professor, Department of Water Supply, Water Disposal and Water Purification, O. M. Beketov National University of Urban Economy in Kharkiv, Ukraine, e-mail: Mashunka220982@gmail.com, ORCID: http://orcid.org/ 0000-0001-7836-1680 